\title{
Desulfotignum toluenicum sp. nov., a novel toluene-degrading, sulphate-reducing bacterium isolated from an oil-reservoir model column
}

Correspondence

Terje Torsvik

terje.torsvik@bio.uib.no

\author{
Hege Ommedal ${ }^{1,2}$ and Terje Torsvik ${ }^{1}$ \\ ${ }^{1}$ University of Bergen, Centre for Integrated Petroleum Research (CIPR), Allégaten 41, \\ N-5007 Bergen, Norway \\ ${ }^{2}$ University of Bergen, Department of Biology, Jahnebakken 5, N-5020 Bergen, Norway
}

\begin{abstract}
A Gram-negative, sulphate-reducing bacterium (strain $\mathrm{H}^{\top}$ ) was isolated from an oil-reservoir model column. The new isolate was able to oxidize toluene coupled to hydrogen sulphide production. For growth, the optimum salt concentration was $1.5 \%(\mathrm{w} / \mathrm{v})$, the optimum pH was 7.2 and the optimum temperature was $34^{\circ} \mathrm{C}$. The cells were straight to slightly curved rods, $0.6-1.0 \mu \mathrm{m}$ in diameter and $1.4-2.5 \mu \mathrm{m}$ in length. The predominant fatty acids were $C_{16: 0}$, $\mathrm{C}_{16: 1} \omega 7 \mathrm{c}$ and $\mathrm{C}_{17: 0} \mathrm{cyclo}$, and the cells also contained dimethylacetals. Cloning and sequencing of a $1505 \mathrm{bp}$ long fragment of the $16 \mathrm{~S}$ rRNA gene showed that strain $\mathrm{H}^{\top}{ }^{\top}$ is a member of the Deltaproteobacteria and is related closely to Desulfotignum balticum DSM $7044^{\top}$. The $G+C$ content of the DNA was 52.0 mol\% and the DNA-DNA similarity to D. balticum DSM $7044^{\top}$ was $56.1 \%$. Based on differences in DNA sequence and the unique property of toluene degradation, it is proposed that strain $\mathrm{H}^{\top}$ should be designated a member of a novel species within the genus Desulfotignum, for which the name Desulfotignum toluenicum sp. nov. is proposed. The

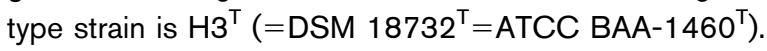

The genus Desulfotignum was established when the mesophilic, sulphate-reducing strain SAX (Drzyzga et al., 1993) was described as Desulfotignum balticum (Kuever et al., 2001). The type strain, Desulfotignum balticum DSM $7044^{\mathrm{T}}$, has the ability to oxidize aromatic compounds such as benzoic acid and 4-hydroxybenzoate, but does not oxidize toluene. The genus also contains the sulphate-reducing bacterium Desulfotignum phosphitoxidans, which grows lithoautotrophically with phosphite as electron donor and sulphate as electron acceptor (Schink et al., 2002).

Strain $\mathrm{H} 3^{\mathrm{T}}$ was isolated from an anaerobic enrichment culture inoculated with bacteria from an oil-reservoir model column (Myhr et al., 2002), supplied with $0.8 \%$ $(\mathrm{v} / \mathrm{v})$ crude oil as the only carbon source. The enrichment culture was diluted serially with crude oil as carbon source in reduced bicarbonate-buffered seawater medium (Widdel \& Pfennig, 1981) modified to $1.2 \mathrm{~g} \mathrm{KH}_{2} \mathrm{PO}_{4} \mathrm{l}^{-1}$ and $0.25 \mathrm{~g}$ $\mathrm{NH}_{4} \mathrm{Cl} \mathrm{l}^{-1}$ (W20). The $10^{-7}$ dilution was submitted to an

The GenBank/EMBL/DDBJ accession numbers for the 16S rRNA gene sequences determined in this study are EF207157-EF207159 for strain $\mathrm{H}^{\top}$ clone sequences 1, 4 and 7, respectively.

A supplementary table showing the varying bases in the analysed Desulfotignum sp. 16S rRNA gene sequences, and supplementary figures showing a transmission electron micrograph of unstained cells of Desulfotignum toluenicum $\mathrm{H}^{\top}$ and rep-PCR profiles for the analysed strains of Desulfotignum, are available with the online version of this paper. anoxic agar dilution series (Widdel \& Bak, 1992) with $10 \mathrm{mM}$ sodium caproate. After four consecutive agar dilution series of bacteria originating from the $10^{-7}$ dilution described above, three beige-coloured colonies (strains $\mathrm{H} 1, \mathrm{H} 2$ and $\mathrm{H}^{\mathrm{T}}$ ) were picked and propagated in W20 with caproate $(10 \mathrm{mM})$. Strain $\mathrm{H}^{\mathrm{T}}$ was characterized fully. Desulfotignum balticum DSM $7044^{\mathrm{T}}$ was purchased from the Deutsche Sammlung von Mikroorganismen und Zellkulturen (DSMZ; Braunschweig, Germany).

Growth was monitored by light microscopy in a Zeiss phasecontrast microscope and by hydrogen sulphide measurements (Cord-Ruwisch, 1985). Cells were counted in a Thoma chamber, but cell counts were difficult in cultures supplied with crude oil, due to disturbances from oil in the preparations. Transmission electron microscopy (TEM) of unstained preparations of strain $\mathrm{H}^{\mathrm{T}}$ was done at the electron microscope facilities at the University of Bergen, Norway. TEM images with size bars were used to determine the cell size. Salt requirement for growth was tested in DSMZ medium 383a (http://www.dsmz.de/media/med383a.htm) in triplicate with $0-60 \mathrm{~g} \mathrm{NaCl} \mathrm{l}^{-1}$ in intervals of $5.0 \mathrm{~g} \mathrm{l}^{-1}$ $\left(\mathrm{pH} \mathrm{7.0,30}{ }^{\circ} \mathrm{C}\right)$. The $\mathrm{pH}$ range for growth was tested in triplicate as described by Knoblauch et al. (1999) in medium 383 a adjusted to a pH value between 4.94 and $9.06\left(30{ }^{\circ} \mathrm{C}\right)$ and the temperature optimum was tested in duplicate in medium 383a in a temperature-gradient block with temperatures between 9.9 and $48.2{ }^{\circ} \mathrm{C}(\mathrm{pH} 7.0)$. 
Gram typing was determined by thorough mixing of cells of strain $\mathrm{H}^{\mathrm{T}}$ in a drop of $3 \%(\mathrm{w} / \mathrm{v}) \mathrm{KOH}$ on a glass slide, followed by incubation at room temperature for $1 \mathrm{~min}$. Catalase activity was tested in $3 \%(\mathrm{v} / \mathrm{v})$ hydrogen peroxide.

The fatty acid composition, DNA base composition and DNA-DNA hybridization value to Desulfotignum balticum DSM $7044^{\mathrm{T}}$ were determined at the DSMZ by standard protocols.

Cells of strain $\mathrm{H} 3^{\mathrm{T}}$ were $0.6-1.0 \mu \mathrm{m}$ in diameter and 1.4$2.5 \mu \mathrm{m}$ in length. The cell shape varied from short blunt rods, almost cigar-shaped in the early growth phase, to long and slightly curved rods in late exponential phase. The cells were covered with an extracellular layer that appeared like a halo around the cells. Turbid, well-grown cultures had a strong tendency to attach to the inner walls of the growth tubes. A TEM image of strain $\mathrm{H} 3^{\mathrm{T}}$ is available as Supplementary Fig. S1 in IJSEM Online. Growth occurred between 0.5 and $5.5 \%(\mathrm{w} / \mathrm{v}) \mathrm{NaCl}$ (optimum, $1.5 \%$ ), between $\mathrm{pH} 6.5$ and 9.0 (optimum, 7.2) and between 16 and $35{ }^{\circ} \mathrm{C}$ (optimum, $34{ }^{\circ} \mathrm{C}$ ). Strain $\mathrm{H} 3{ }^{\mathrm{T}}$ was Gramnegative and catalase-positive.

The predominant fatty acids were $16: 0(20.3 \%), 16: 1 \omega 7 c$ $(14.0 \%)$ and $17: 0$ cyclo $(13.4 \%)$ and, in addition, four different dimethylacetals were found that were unique to strain $\mathrm{H}^{\mathrm{T}}$ (Table 1). The DNA $\mathrm{G}+\mathrm{C}$ content was determined as $52.0 \mathrm{~mol} \%$ and the DNA-DNA hybridization value to Desulfotignum balticum DSM $7044^{\mathrm{T}}$ was $56.1 \%$.

Growth on crude oil as carbon source was tested in W20 or in medium 383a with 1.4 or $5.6 \%(\mathrm{v} / \mathrm{v})$ anoxic sterile crude oil, respectively, supplied through an $\mathrm{N}_{2}$-flushed syringe. $n$ Alkanes $\left(n \mathrm{C}_{7}-n \mathrm{C}_{9}\right.$ and $\left.n \mathrm{C}_{12}\right)$, toluene, ethylbenzene and $o-$, $m$-, or $p$-xylene were diluted $2 \%(\mathrm{v} / \mathrm{v})$ in heptamethylnonane (Harms et al., 1999) before $0.5 \mathrm{ml}$ sterile and anoxic hydrocarbon solution was added per $16 \mathrm{ml}$ culture. The culture tubes were incubated in a near-horizontal position with the orifices below the liquid surface (Widdel et al., 2006). In addition to strain $\mathrm{H}^{\mathrm{T}}$, Desulfotignum balticum DSM $7044^{\mathrm{T}}$ was tested with toluene and crude oil as carbon sources. Strain $\mathrm{H}^{\mathrm{T}}$ grew with toluene and crude oil (Fig. 1a, b), whereas Desulfotignum balticum DSM $7044^{\mathrm{T}}$ did not, and whole-oil GC (Skaare, 2007) showed that $4.4 \mathrm{mM}$ of the toluene naturally present in crude oil was depleted from the oil when $8.1 \mathrm{mM} \mathrm{H} \mathrm{H}_{2} \mathrm{~S}$ was produced after 50 days incubation (Fig. 1b). Strain $\mathrm{H}^{\mathrm{T}}$ is the first member of the genus Desulfotignum with the ability to grow solely on a monoaromatic hydrocarbon, i.e. toluene. Intermediate products from incomplete hydrocarbon oxidation were not detected by GC, which indicated complete oxidation of toluene to $\mathrm{CO}_{2}$. The $\mathrm{H}_{2} \mathrm{~S}$ : toluene molar ratio during growth on toluene was approximately 2, which was lower than the 4.12 ratio shown for Desulfobacula toluolica DSM $7467^{\mathrm{T}}$ (Rabus et al., 1993). The results from the complete substrate analysis for strain $\mathrm{H}^{\mathrm{T}}$ are listed in Table 2.

A reverse primer (5'-CTTCACCCCAGTTATCAACC-3') was constructed for PCR amplification of the 16S rRNA
Table 1. Fatty acid content of strain $\mathrm{H}^{\top}$ and closely related species

Percentage of total fatty acids is shown. Taxa: 1 , strain $\mathrm{H}^{\mathrm{T}} ; 2$, Desulfotignum balticum DSM $7044^{\mathrm{T}}$; 3 , Desulfobacula toluolica DSM $7467^{\mathrm{T}} ; 4$, Desulfobacula phenolica DSM $3384^{\mathrm{T}} ; 5$, Desulfospira joergensenii DSM $10085^{\mathrm{T}}$. Data for taxa $2-5$ are from Kuever et al. (2001). Abbreviations: OH, hydroxy; Me, methyl; DMA, dimethylacetal; i, iso; cyc, cyclopropane.

\begin{tabular}{|c|c|c|c|c|c|}
\hline Fatty acid & 1 & 2 & 3 & 4 & 5 \\
\hline $14: 0$ & 8.5 & 3.7 & 8.3 & 8.7 & 13.9 \\
\hline $15: 0$ & 6.3 & 0.2 & 1.6 & 2.0 & 1.3 \\
\hline $16: 0$ & 20.3 & 24.2 & 31.2 & 20.4 & 28.4 \\
\hline $17: 0$ & 6.2 & 0.4 & 0.7 & 0.7 & 0.6 \\
\hline $18: 0$ & 4.6 & 9.8 & 3.1 & 2.1 & 0.7 \\
\hline i15: 0 & - & - & - & - & 1.8 \\
\hline $\mathrm{i} 19: 0$ & - & 1.7 & 2.5 & - & - \\
\hline $14: 1$ & - & - & - & 1.4 & - \\
\hline $15: 1 \omega 6 c$ & 2.2 & - & - & - & - \\
\hline $15: 1 \omega 9 c$ & - & 0.8 & - & - & - \\
\hline $16: 1 \omega 5 c$ & 1.0 & - & - & - & - \\
\hline $16: 1 \omega 7 c$ & 14.0 & - & - & - & - \\
\hline $16: 1 \omega 9 c$ & - & 8.5 & 19.7 & 16.5 & 38.9 \\
\hline $18: 1 \omega 9 c$ & 1.7 & 3.7 & - & - & - \\
\hline $18: 1 \omega 11 c$ & - & 7.4 & 6.0 & 3.9 & 5.3 \\
\hline $3-\mathrm{OH} 14: 0$ & - & - & - & 1.3 & 1.6 \\
\hline $3-\mathrm{OH} 15: 0$ & 1.4 & - & - & - & - \\
\hline $3-\mathrm{OH} 16: 0$ & 2.1 & - & - & - & 2.3 \\
\hline 10-Me 16:0 & - & 14.0 & 17.6 & 17.2 & - \\
\hline 14:0 DMA & 2.7 & - & - & - & - \\
\hline $16: 1 \omega 7 c$ DMA & 0.6 & - & - & - & - \\
\hline 16:0 DMA & 4.0 & - & - & - & - \\
\hline $17: 0$ DMA & 0.7 & - & - & - & - \\
\hline $17: 0$ сус & 13.4 & 19.5 & 2.6 & 3.9 & 2.4 \\
\hline $19: 0$ сус & - & 1.1 & - & - & - \\
\hline 16:0 aldehyde & 1.2 & - & - & - & - \\
\hline
\end{tabular}

gene from strain $\mathrm{H}^{\mathrm{T}}$, as the normally used $1525 \mathrm{r}$ primer (Lane, 1991) did not have a complementary sequence in the 16S rRNA gene of the reference strain Desulfotignum balticum DSM $7044^{\mathrm{T}}$. Combined with the primer A8f (Edwards et al., 1989), a 1505 bp long DNA fragment was PCR-amplified by standard protocols, cloned into the pCR4-TOPO vector (Invitrogen) and sequenced by using the primers T3, T7 (Invitrogen) and 338f (Lane, 1991). The partial sequences were assembled to a consensus sequence by using the Institut Pasteur CAP alignment tool (http:// www.pasteur.fr/english.html). Cloning and sequencing of the 16S rRNA gene resulted in seven distinct sequences, with reciprocal sequence similarity between 98.6 and $99.9 \%$. Three clone sequences, 1,4 and 7 , were chosen to represent strain $\mathrm{H}^{\mathrm{T}}{ }^{\mathrm{T}}$ in GenBank and submitted under the accession numbers EF207157 (clone 1), EF207158 (clone 4) and EF207159 (clone 7), as demonstrated previously for novel Clostridium species (Spring et al., 2003). All variable nucleotides are presented in Supplementary Table S1 in IJSEM Online. 

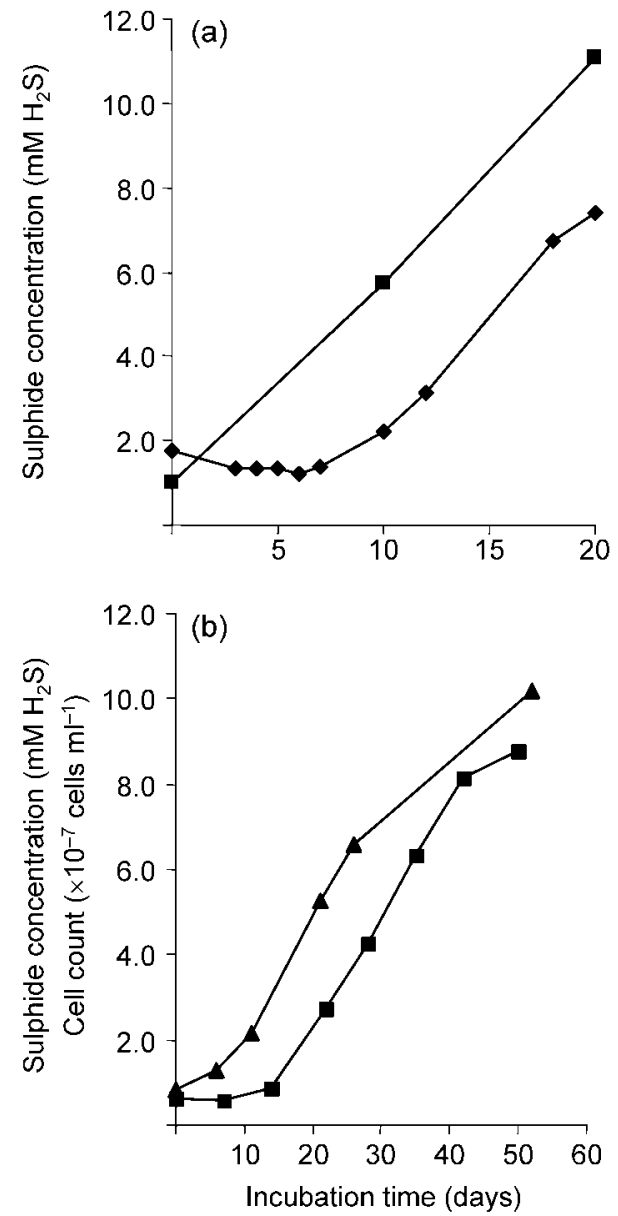

Fig. 1. Growth of strain $\mathrm{H}^{\top}$ on hydrocarbons. (a) Growth with toluene as carbon source. The $\mathrm{H}_{2} \mathrm{~S}$ concentration curve $(\boldsymbol{})$ and cell counts ( $\square$ ) are shown. (b) $\mathrm{H}_{2} \mathrm{~S}$ concentrations produced with crude oil $(\boldsymbol{\square})$ and toluene $(\boldsymbol{\Lambda})$ as carbon sources.

CAP-assembled clone sequences were aligned in CLUSTAL_X (Thompson et al., 1997) to 16S rRNA gene sequences of members of the Deltaproteobacteria available in GenBank (Benson et al., 2004), obtained by BLAST search (Wheeler et al., 2003). Similarity values between sequences were calculated by using the Matrix Global Alignment Tool (MatGAT; Campanella et al., 2003). The phylogenetic relationships were presented graphically in a neighbourjoining tree (Saitou \& Nei, 1987) based on the CLUSTAL_X alignment of the 16S rRNA gene sequences, with Escherichia coli as outgroup (Fig. 2). The tree was bootstrapped by 1000 recalculations and evaluated by the maximum-parsimony and maximum-likelihood algorithms (PHYLIP software package; Felsenstein, 2001). The $16 \mathrm{~S}$ rRNA gene sequences of clones of strain $\mathrm{H}^{\mathrm{T}}$ were 98.7-99.9\% similar to that of Desulfotignum balticum DSM $7044^{\mathrm{T}}$, and placed strain $\mathrm{H}^{\mathrm{T}}$ within the genus Desulfotignum. Still, the DNA-DNA hybridization value of $56.1 \%$ to Desulfotignum balticum DSM $7044^{\mathrm{T}}$ showed that the novel strain $\mathrm{H}^{\mathrm{T}}$ did not belong to the species
Table 2. Physiological characterization of the type strains of species within the genus Desulfotignum

Taxa: 1, strain $\mathrm{H} 3^{\mathrm{T}} ; 2$, Desulfotignum balticum DSM $7044^{\mathrm{T}} ; 3$, Desulfotignum phosphitoxidans FiPS- $3^{\mathrm{T}}$. Data for taxon 2 were obtained from Kuever et al. (2001) and Drzyzga et al. (1993) and those for taxon 3 from Schink et al. (2002). +, Positive; (+), weakly positive; - , negative; ND, not determined. All taxa were positive for pyruvate, fumarate, sulphate and sulphite tests.

\begin{tabular}{|c|c|c|c|}
\hline Test & 1 & 2 & 3 \\
\hline Crude oil & + & $-^{*}$ & ND \\
\hline $\mathrm{C}_{7}-\mathrm{C}_{9} n$-alkanes & - & ND & ND \\
\hline $\mathrm{C}_{12} n$-alkanes & - & ND & $\mathrm{ND}$ \\
\hline Toluene & + & $-{ }^{\star}$ & $(+)$ \\
\hline Ethylbenzene & - & ND & ND \\
\hline m-Xylene & - & ND & ND \\
\hline p-Xylene & - & $\mathrm{ND}$ & $\mathrm{ND}$ \\
\hline$o$-Xylene & - & $\mathrm{ND}$ & $\mathrm{ND}$ \\
\hline Phenol & ND & $(+)$ & + \\
\hline Phenylacetate & $\mathrm{ND}$ & $(+)$ & ND \\
\hline Benzoate & + & + & ND \\
\hline 4-hydroxybenzoate & + & + & $\mathrm{ND}$ \\
\hline $\mathrm{H}_{2} / \mathrm{CO}_{2}$ & + & $(+)$ & + \\
\hline Formate & + & $(+)$ & + \\
\hline Acetate & + & $(+)$ & - \\
\hline Lactate & - & + & - \\
\hline Butyrate, $\mathrm{C}_{4}$ & + & + & - \\
\hline Valerate, $\mathrm{C}_{5}$ & - & $\mathrm{ND}$ & ND \\
\hline Caproate, $\mathrm{C}_{6}$ & + & $\mathrm{ND}$ & ND \\
\hline Heptanoate, $\mathrm{C}_{7}$ & + & ND & ND \\
\hline Nonate, $\mathrm{C}_{9}$ & + & $\mathrm{ND}$ & $\mathrm{ND}$ \\
\hline Decanoate, $\mathrm{C}_{10}$ & + & $(+)$ & ND \\
\hline Undecanoate, $\mathrm{C}_{11}$ & - & $\mathrm{ND}$ & $\mathrm{ND}$ \\
\hline Dodecanoate, $\mathrm{C}_{12}$ & - & $(+)$ & $\mathrm{ND}$ \\
\hline Tetradecanonate, $\mathrm{C}_{14}$ & $(+)$ & $\mathrm{ND}$ & $\mathrm{ND}$ \\
\hline Hexadecanoate, $\mathrm{C}_{16}$ & + & $(+)$ & ND \\
\hline Octadecanoate, $\mathrm{C}_{18}$ & - & ND & ND \\
\hline Ethanol & - & - & ND \\
\hline Succinate & + & $(+)$ & ND \\
\hline Malate & - & + & + \\
\hline Fermentation of pyruvate & + & + & - \\
\hline Vitamins & + & + & $\mathrm{ND}$ \\
\hline Thiosulphate & - & + & + \\
\hline Elementary sulphur & - & $\mathrm{ND}$ & - \\
\hline
\end{tabular}

${ }^{\star}$ Growth on crude oil and toluene for Desulfotignum balticum DSM $7044^{\mathrm{T}}$ was tested in this study.

Desulfotignum balticum (Wayne et al., 1987) and defined strain $\mathrm{H}^{\mathrm{T}}$ as a member of a novel species within the genus Desulfotignum. Strain $\mathrm{H}^{\mathrm{T}}$ was also related to Desulfobacula toluolica DSM $7467^{\mathrm{T}}$ (Rabus et al., 1993) and Desulfobacula phenolica DSM $3384^{\mathrm{T}}$ (Kuever et al., 2001), which have been shown to degrade toluene. Sulphate-reducing bacteria able to degrade aliphatic hydrocarbons, Desulfoglaeba alkanexedens ALDC $^{\mathrm{T}}$ (Davidova et al., 2006), strain Hxd3 (Aeckersberg et al., 1991), Desulfatibacillum aliphaticivorans $\mathrm{CV} 2803^{\mathrm{T}}$ (Cravo-Laureau et al., 2004), strain Pnd3 


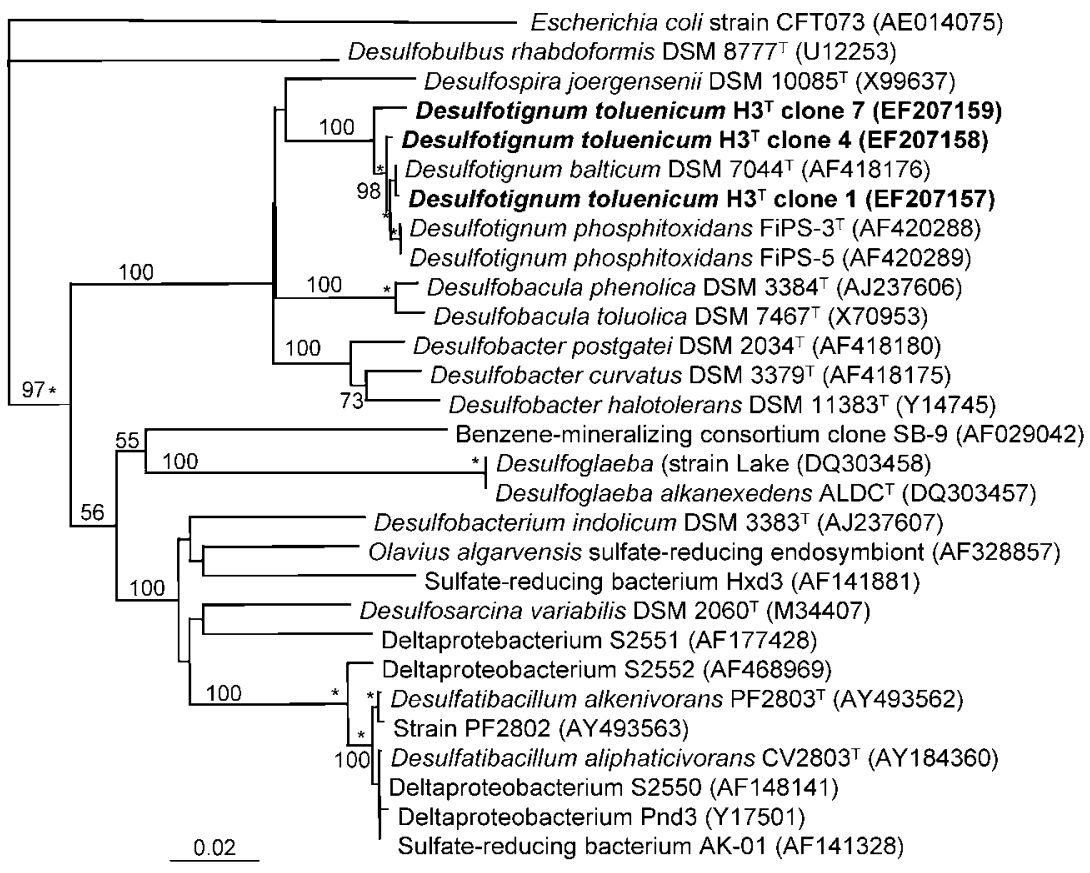

Fig. 2. Phylogenetic tree showing the affiliation of the 16S rRNA gene sequences of Desulfotignum toluenicum $\mathrm{H}^{\top}$ (shown in bold) within the Deltaproteobacteria, with Escherichia coli as outgroup. GenBank accession numbers are shown in parentheses. The tree was calculated by the neighbour-joining method. Asterisks show branches also resolved by the maximum-likelihood and maximum-parsimony algorithms (Einen \& Ovreas, 2006). Bootstrap values (1000 recalculations) $>50 \%$ are shown. Bar, 0.02 substitutions per nucleotide.
(Aeckersberg et al., 1998) and strain AK-01 (So \& Young, 1999), were affiliated to remote clusters.

Strain-specific genomic fingerprint analyses by repetitive PCR (rep-PCR) (Stern et al., 1984; Versalovic et al., 1991) were performed with whole cells; extracted DNA was obtained by using a FastDNA SPIN kit for soil (Qbiogene). Strains $\mathrm{H}^{\mathrm{T}}$ and Desulfotignum balticum DSM $7044^{\mathrm{T}}$ had very similar genomic fingerprints, but differed by the lack of bands of approximately 450 and $900 \mathrm{bp}$ in the fingerprint of Desulfotignum balticum DSM $7044^{\mathrm{T}}$. A picture showing the rep-PCR patterns for the analysed Desulfotignum species is available as Supplementary Fig. S2 in IJSEM Online.

Based on the DNA-DNA hybridization value of $56.1 \%$ to Desulfotignum balticum DSM $7044^{\mathrm{T}}$, the fatty acid composition and the ability to degrade toluene, we conclude that strain $\mathrm{H} 3^{\mathrm{T}}$ should be assigned to a novel species within the genus Desulfotignum, for which the name Desulfotignum toluenicum sp. nov. is proposed.

\section{Description of Desulfotignum toluenicum sp. nov.}

Desulfotignum toluenicum (tol.u.en'i.cum. N.L. n. toluenum toluene; L. suff. -icus - $a$-um suffix used with the sense of belonging to; N.L. neut. adj. toluenicum pertaining to toluene).

Rod-shaped, mesophilic, Gram-negative and sulphatereducing. Cells are $0.6-1.0 \mu \mathrm{m}$ in diameter and 1.4-2.5 $\mu \mathrm{m}$ in length, and have a tendency to curve with ageing. Motility is not observed and there are no flagella. Growth occurs at $\mathrm{NaCl}$ concentrations between 0.5 and $5.5 \%(\mathrm{v} / \mathrm{w})$, with optimum growth at $1.5 \% \mathrm{NaCl}$, at temperatures between 16 and $35{ }^{\circ} \mathrm{C}$ (optimum, $34{ }^{\circ} \mathrm{C}$ ) and at $\mathrm{pH}$ values between 6.5 and 9.0 (optimum, 7.2). The predominant fatty acids are $\mathrm{C}_{16: 0}, \mathrm{C}_{16: 1} \omega 7 c$ and $\mathrm{C}_{17: 0}$ cyclo and the cells also contain dimethylacetals. Catalase-positive. The following are used as substrates for growth: toluene, crude oil, formate, benzoate, 4-hydroxybenzoate, acetate, butyrate, caproate, heptanoate, nonate, decanoate, tetradecanonate, hexadecanoate, pyruvate, fumarate, succinate and $\mathrm{H}_{2} / \mathrm{CO}_{2}$. Vitamins are required for growth. $n$-Alkanes $\left(n \mathrm{C}_{7}-n \mathrm{C}_{9}\right.$ and $\left.n \mathrm{C}_{12}\right)$, ethylbenzene, $m$-, $p$-, or $o$-xylene, lactate, valerate, undecanoate, dodecanoate, octadecanoate, ethanol and malate are not used as substrates. Electron acceptors are sulphate and sulphite. No growth was observed with thiosulphate or elemental sulphur as electron acceptor or with caproate as electron donor. The DNA G $+\mathrm{C}$ content is $52.0 \mathrm{~mol} \%$.

The type strain, $\mathrm{H}^{\mathrm{T}}\left(=\mathrm{DSM} 18732^{\mathrm{T}}=\right.$ ATCC BAA- $\left.1460^{\mathrm{T}}\right)$, was isolated from an oil-reservoir model column at the University of Bergen, Norway.

\section{Acknowledgements}

We are indebted to Bent Barman Skaare for performing the whole-oil GC analysis and to Mikal Heldal for TEM. We thank Dr K. Droenen for performing the rep-PCR analysis and for valuable comments on the manuscript, and Dr J. Einen for help during construction of the maximum-likelihood and maximum-parsimony phylogenetic trees. We are grateful to Bente Thorbjoernsen, Rikke Helen Ulvoen and Tove Leiknes for technical assistance. The work was funded by the Norwegian Research Council through the CIPR, University of Bergen, Norway.

\section{References}

Aeckersberg, F., Bak, F. \& Widdel, F. (1991). Anaerobic oxidation of saturated hydrocarbons to $\mathrm{CO}_{2}$ by a new type of sulfate-reducing bacterium. Arch Microbiol 156, 5-14. 
Aeckersberg, F., Rainey, F. A. \& Widdel, F. (1998). Growth, natural relationships, cellular fatty acids and metabolic adaptation of sulfatereducing bacteria that utilize long-chain alkanes under anoxic conditions. Arch Microbiol 170, 361-369.

Benson, D. A., Karsch-Mizrachi, I., Lipman, D. J., Ostell, J. \& Wheeler, D. L. (2004). GenBank: update. Nucleic Acids Res 32, D23-D26.

Campanella, J. J., Bitincka, L. \& Smalley, J. (2003). MatGAT: an application that generates similarity/identity matrices using protein or DNA sequences. BMC Bioinformatics 4, 29.

Cord-Ruwisch, R. (1985). A quick method for the determination of dissolved and precipitated sulfides in cultures of sulfate-reducing bacteria. J Microbiol Methods 4, 33-36.

Cravo-Laureau, C., Matheron, R., Cayol, J. L., Joulian, C. \& HirschlerRea, A. (2004). Desulfatibacillum aliphaticivorans gen. nov., sp nov., an $n$-alkane- and $n$-alkene-degrading, sulfate-reducing bacterium. Int J Syst Evol Microbiol 54, 77-83.

Davidova, I., Duncan, K. E., Choi, O. K. \& Suflita, J. M. (2006). Desulfoglaeba alkanexedens gen. nov., sp. nov., an $n$-alkane-degrading, sulfate-reducing bacterium. Int J Syst Evol Microbiol 56, 2737-2742.

Drzyzga, O., Küver, J. \& Blotevogel, K.-H. (1993). Complete oxidation of benzoate and 4-hydroxybenzoate by a new sulfate-reducing bacterium resembling Desulfoarculus. Arch Microbiol 159, 109-113.

Edwards, U., Rogall, T., Blocker, H., Emde, M. \& Bottger, E. C. (1989). Isolation and direct complete nucleotide determination of entire genes. Characterization of a gene coding for $16 \mathrm{~S}$ ribosomal RNA. Nucleic Acids Res 17, 7843-7853.

Einen, J. \& Ovreas, L. (2006). Flaviramulus basaltis gen. nov., sp nov., a novel member of the family Flavobacteriaceae isolated from seafloor basalt. Int J Syst Evol Microbiol 56, 2455-2461.

Felsenstein, J. (2001). PHYLIP (phylogeny inference package), version 3.6. Seattle, WA: Department of Genetics, University of Washington.

Harms, G., Zengler, K., Rabus, R., Aeckersberg, F., Minz, D., Rossello-Mora, R. \& Widdel, F. (1999). Anaerobic oxidation of $o$ xylene, $m$-xylene, and homologous alkylbenzenes by new types of sulfate-reducing bacteria. Appl Environ Microbiol 65, 999-1004.

Knoblauch, C., Sahm, K. \& Jørgensen, B. B. (1999). Psychrophilic sulfate-reducing bacteria isolated from permanently cold Arctic marine sediments: description of Desulfofrigus oceanense gen. nov., sp. nov., Desulfofrigus fragile sp. nov., Desulfofaba gelida gen. nov., sp. nov., Desulfotalea psychrophila gen. nov., sp. nov. and Desulfotalea arctica sp. nov. Int J Syst Bacteriol 49, 1631-1643.

Kuever, J., Könneke, M., Galushko, A. \& Drzyzga, O. (2001). Reclassification of Desulfobacterium phenolicum as Desulfobacula phenolica comb. nov. and description of strain $\mathrm{Sax}^{\mathrm{T}}$ as Desulfotignum balticum gen. nov., sp. nov. Int J Syst Evol Microbiol 51, 171-177.

Lane, D. J. (1991). 16S/23S rRNA sequencing. In Nucleic Acid Techniques in Bacterial Systematics, pp. 115-175. Edited by E. Stackebrandt \& M. Goodfellow. Chichester: Wiley.

Myhr, S., Lillebo, B. L. P., Sunde, E., Beeder, J. \& Torsvik, T. (2002). Inhibition of microbial $\mathrm{H}_{2} \mathrm{~S}$ production in an oil reservoir model column by nitrate injection. Appl Microbiol Biotechnol 58, 400-408.

Rabus, R., Nordhaus, R., Ludwig, W. \& Widdel, F. (1993). Complete oxidation of toluene under strictly anoxic conditions by a new sulfatereducing bacterium. Appl Environ Microbiol 59, 1444-1451.
Saitou, N. \& Nei, M. (1987). The neighbor-joining method: a new method for reconstructing phylogenetic trees. Mol Biol Evol 4, 406-425.

Schink, B., Thiemann, V., Laue, H. \& Friedrich, M. W. (2002). Desulfotignum phosphitoxidans sp. nov., a new marine sulfate reducer that oxidizes phosphite to phosphate. Arch Microbiol 177, 381-391.

Skaare, B. B. (2007). Effects of initial anaerobic biodegradation on crude oil and formation water composition. $\mathrm{PhD}$ dissertation, Department of Chemistry, University of Bergen, Norway.

So, C. M. \& Young, L. Y. (1999). Isolation and characterization of a sulfate-reducing bacterium that anaerobically degrades alkanes. Appl Environ Microbiol 65, 2969-2976.

Spring, S., Merkhoffer, B., Weiss, N., Kroppenstedt, R. M., Hippe, H. \& Stackebrandt, E. (2003). Characterization of novel psychrophilic clostridia from an Antarctic microbial mat: description of Clostridium frigoris sp. nov., Clostridium lacusfryxellense sp. nov., Clostridium bowmanii sp. nov. and Clostridium psychrophilum sp. nov. and reclassification of Clostridium laramiense as Clostridium estertheticum subsp. laramiense subsp. nov. Int J Syst Evol Microbiol 53, 1019-1029.

Stern, M. J., Ames, G. F. L., Smith, N. H., Robinson, E. C. \& Higgins, C. F. (1984). Repetitive extragenic palindromic sequences - a major component of the bacterial genome. Cell 37, 1015-1026.

Thompson, J. D., Gibson, T. J., Plewniak, F., Jeanmougin, F. \& Higgins, D. G. (1997). The CLUSTAL_X windows interface: flexible strategies for multiple sequence alignment aided by quality analysis tools. Nucleic Acids Res 25, 4876-4882.

Versalovic, J., Koeuth, T. \& Lupski, J. R. (1991). Distribution of repetitive DNA-sequences in eubacteria and application to fingerprinting of bacterial genomes. Nucleic Acids Res 19, 6823-6831.

Wayne, L. G., Brenner, D. J., Colwell, R. R., Grimont, P. A. D., Kandler, O., Krichevsky, M. I., Moore, L. H., Moore, W. E. C., Murray, R. G. E. \& other authors (1987). International Committee on Systematic Bacteriology. Report of the ad. hoc committee on reconciliation of approaches to bacterial systematics. Int J Syst Bacteriol 37, 463-464.

Wheeler, D. L., Church, D. M., Federhen, S., Lash, A. E., Madden, T. L., Pontius, J. U., Schuler, G. D., Schriml, L. M., Sequeira, E. \& other authors (2003). Database resources of the National Center for Biotechnology. Nucleic Acids Res 31, 28-33.

Widdel, F. \& Bak, F. (1992). Gram-negative mesophilic sulfatereducing bacteria. In The Prokaryotes: a Handbook on the Biology of Bacteria. Ecophysiology, Isolation, Identification, Applications, 2nd edn, pp. 3352-3378. Edited by A. Balows, H. G. Trüper, M. Dworkin, W. Harder \& K.-H. Schleifer. New York: Springer Verlag.

Widdel, F. \& Pfennig, N. (1981). Studies on dissimilatory sulfatereducing bacteria that decompose fatty acids. I. Isolation of new sulfate-reducing bacteria enriched with acetate from saline environments. Description of Desulfobacter postgatei gen. nov., sp. nov. Arch Microbiol 129, 395-400.

Widdel, F., Boetius, A. \& Rabus, R. (2006). Anaerobic biodegradation of hydrocarbons including methane. In The Prokaryotes: an Evolving Electronic Resource for the Microbiological Community, pp. 1028-1049. Edited by M. Dworkin, S. Falkow, E. Rosenberg, K.-H. Schleifer \& E. Stackebrandt. New York: Springer. 